\title{
Methodology for scaling finite element dummy and validation of a Hybrid III dummy model in crashworthiness simulation
}

\author{
Anh Hung Ly ${ }^{1,2, *}$, Bao Dinh Nguyen ${ }^{1,2}$, Huy Anh Nguyen ${ }^{1,2}$
}

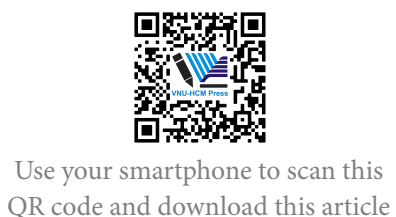

QR code and download this article

${ }^{1}$ Falcuty of Transportation Engineering, Ho Chi Minh City University of Technology

${ }^{2}$ Viet Nam National University Ho Chi Minh City

\section{Correspondence}

Anh Hung Ly, Falcuty of Transportation Engineering, Ho Chi Minh City University of Technology

Viet Nam National University Ho Chi Minh City

Email: lyhunganh@hcmut.edu.vn

\section{History}

- Received: 06-3-2019

- Accepted: 17-6-2019

- Published: 31-12-2019

DOI :10.32508/stdjet.v2iSI2.468

\section{Check for updates}

\section{Copyright}

(อ) VNU-HCM Press. This is an openaccess article distributed under the terms of the Creative Commons Attribution 4.0 International license.

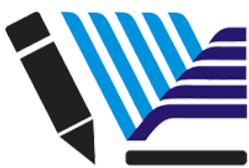

VNU-HCM Press

ABSTRACT

For study of car-pedestrian crashes, it is two common methods that can be employed: conducting crash tests with mechanical dummies and simulating car crashes on computer. The former is a traditional way and gives good results compared with real life car impact; however, its disadvantage is very expensive test equipment and generally more time-consuming than the latter because after every crash test, experimental vehicles as well as dummies need repairing to be ready for the next experiments. Therefore, crash test simulation using finite-element method is more and more popular in the automobile industry because of its feasibility and cost saving. The majority of finite element dummy models used in crash simulation. Particularly, it is popular to use Hybrid III 50th dummy model which is built based on fiftieth percentile male (equal in height and weight of the average North American). Thus, it is necessary to develop a scaling algorithm to scale a reference dummy size into a desired one without rebuilding the entire model. In this paper, the Hybrid III dummy model provided by LS-DYNA software is scaled to suit Vietnamese biomechanical characteristics. Scaling algorithm comprises dummy geometry, inertial properties and joint properties is utilized. In order to estimate level of head injury - brain concussion by using numerical simulation, the correlation between Head Injury Criterion (HIC) and Abbreviated Injury Scale (AIS) is introduced. In addition, the Hybrid III dummy model in crashworthiness simulation is presented in key frame picture. Numerical simulation approach is validated by comparing results of head acceleration and HIC obtain from this study with experimental data and numerical simulation results in other publication. $^{1-7}$

Key words: Crashworthiness, pedestrian accident, dummy, HIC, acceleration

\section{INTRODUCTION}

Traffic accident is undoubtedly one of the most alarming problems and is the main reason for the increase in deaths in Vietnam as roughly 14,000 people lose their lives each year due to road traffic crashes according to $\mathrm{WHO}^{1}$. In the first nine months of 2018 , the number of road traffic accidents is approximately 13,242 cases in which 6,012 people were dead and 10,319 people were injured. Compared to data in 2017, a number of traffic accidents drop by 1120 cases, and a number of dead people and injured people decreases 113 and 1467 people respectively. Although there is an overall drop in road traffic collisions, it is still one of the leading causes of death in Vietnam. From WHO statistics, motorcyclists make up roughly $59 \%$ of the traffic crashes in the country. It is remarkable that the age group that suffers from the most deaths and injuries on roads is from 15 to 49 years, and this group accounts for $56 \%$ of total population ${ }^{1}$. Moreover, WHO's report in 2017 on traffic accidents per country shows that there are 24.5 road fatalities per 100,000 inhabitants in Vietnam while the average figure in the world is 17 people per 100,000 inhabitants, which demonstrates that the number of fatalities in Vietnam is much higher than that in the world. However, the death probability due to accidents in Vietnam is slightly greater than that in middle-income countries (24.5 and 24.1 respectively) ${ }^{2}$. The report, furthermore, illustrates that the number of traffic fatalities in high-income countries is 9.3 men per 100,000 inhabitants that is much lower than that in low-income and middle-income nations (18.4 and 24.1 respectively) ${ }^{2}$. Another noticeable point is the death proportion in developing countries outnumbers that in poor countries, and it can be reasoned that there are more road vehicles used in developing countries than in poor countries. Figure 1 shows the number of deaths per 100,000 inhabitants according to WHO's report ${ }^{2}$.

\section{METHODOLOGY}

Car crash simulation using finite element method (FEM) becomes more common in car industries in these days because it opens a new modern way for engineers to run crash tests inside computers rather than on roads. In addition, not only does it save 


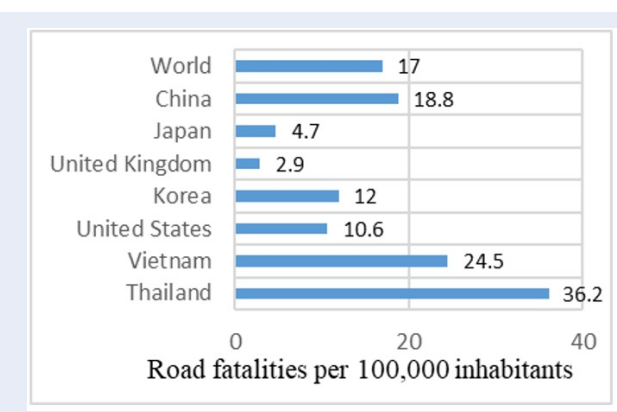

Figure 1: Road fatalities per 100,000 inhabitants

time and be less expensive than real crash tests, it also gives designers and engineers many chances to modify and customize designs for each parts of the car without making changes to the whole models. Therefore, more virtual crash tests run, more insights engineers can gain to fully understand their design to give the best product. As a result, car crash simulation using FEM is a promising and suitable method for the research.

There are many FEM software available nowadays, and some of them are ANSYS, ABAQUS, NASTRAN and LS-DYNA. For this study, LS-DYNA will be chosen because of its capability to simulate highly nonlinear problems including car crashes. Another reason for this choice is LS-DYNA provides a number of dummy models that might be directly used for simulation without any required modifications, and there are many available FEM car model, which can be used in LS-DYNA. Nevertheless, unfortunately, most of LS-DYNA dummy models are constructed based on geometry and biophysical characteristics of the USA or European people. Therefore, it is important to have a scaling algorithm to generate a dummy model representing Vietnamese characteristics from Hybrid III $50^{\text {th }}$ dummy provided by LS-DYNA, after which it is used to perform simulation with different car models to achieve data on injuries of pedestrians in car impact. From simulation data, a database is constructed. A general procedure for this research is shown Figure 2 .

Since Hybrid III 50th dummy model is built based on fiftieth percentile male (equal in height and weight of the average North American), it is required to have a proper scaling method to transform Hybrid III 50th to a dummy model representing Vietnamese. In this study, scaling algorithm for transformation is introduced in ${ }^{5,6}$ and it comprises three steps:

- Scaling of dummy geometry

- Scaling of inertial properties

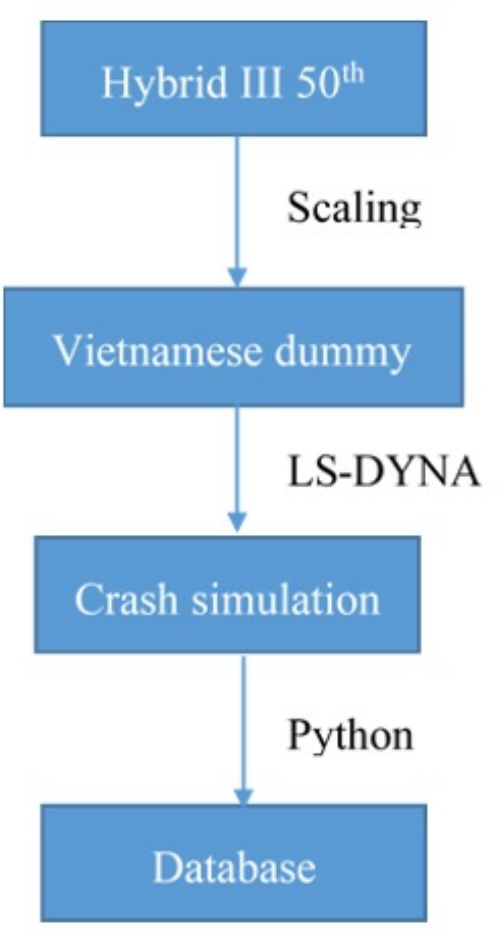

Figure 2: Main procedure for the research

- Scaling of joint properties

In the following sections, three above steps will be discussed in more detail.

\section{Scaling of dummy geometry}

To do geometric scaling, it is necessary to determine size and weight of Hybrid III $50^{\text {th }}$ and scaled dummy (Vietnamese), and they are shown in Table 1.

After these properties have been determined, geometric scaling can be implemented as done in ${ }^{5}$ by using geometric ratios:

Table 1: The table of weight and height of Hybrid III ${ }^{3}$ and Vietnamese dummy ${ }^{4}$

\begin{tabular}{lll}
\hline & Hybrid III & $\begin{array}{l}\text { Vietnamese } \\
\text { dummy }\end{array}$ \\
Height $(\mathrm{cm})$ & 175 & 164 \\
Mass $(\mathrm{kg})$ & 78 & 58 \\
\hline
\end{tabular}

- Scaling in vertical direction ( $\mathrm{z}$ axis) to match height:

$$
\lambda_{z}=\frac{h_{V}}{h_{H y b r i d}}
$$

where $h_{V}$ is Vietnamese height and $h_{\text {Hybrid }}$ is Hybrid III height. 
- Scaling in the other direction (xy plane) to match the mass:

$$
\lambda_{x}=\lambda_{y}=\sqrt{\frac{m_{V}}{m_{H y b r i d} \lambda_{z}}}
$$

where $m_{V}$ is weight of Vietnamese, $m_{\text {Hybrid }}$ is weight of Hybrid III.

Using Equation (1) and (2), Hybrid III $50^{\text {th }}$ is geometrically scaled to match Vietnamese dummy. As a result of applying two above formulas, it yields:

$$
\begin{aligned}
& \lambda_{x}=\lambda_{y}=0.9371 \\
& \lambda_{z}=0.8908
\end{aligned}
$$

The result of geometric scaling is illustrated Figure 3.

\section{Inertial scaling}

When a rigid part's mass and size change, its inertial tensor will be different from original one. Consequently, it is required to update inertial tensor for every part of scaled dummy. A procedure for updating inertial tensor will be done as follows:

- Because each part's inertial tensor of dummy model in LS-DYNA is defined in part's local coordinate (namely oxyz in the Figure 4 ), so it is firstly to compute inertial tensor $\mathrm{I}_{o x^{\prime} y^{\prime} z^{\prime}}$ in ox'y'z', which has the axes parallel to reference coordinate system $\mathrm{O}_{1} \mathrm{x}_{1} \mathrm{y}_{1} \mathrm{z}_{1}$, from inertial tensor $\mathrm{I}_{o x y z}$ using Equation (3):

$$
I_{o x^{\prime} y^{\prime} z^{\prime}}=Q I_{\text {oxyz }} Q^{T}
$$

where $Q$ is rotation matrix from oxyz to ox'y'z' and both of inertial tensor in the formula belong to Hybrid III $50^{\text {th }}$ dummy.

- Compute inertial tensor of scaled dummy $\mathrm{I}_{O X^{\prime} Y^{\prime} Z^{\prime}}$ in OX’Y'Z' from $I_{o x^{\prime} y^{\prime} z^{\prime}}$ using equations from (4) to (9) (See ${ }^{5}$ for formula derivation):

$$
\begin{gathered}
I_{X X}=\lambda_{x} \lambda_{y} \lambda_{z}\left(\lambda_{y}^{2} J_{Y}+\lambda_{z}^{2} J_{z}\right) \\
I_{Y Y}=\lambda_{x} \lambda_{y} \lambda_{z}\left(\lambda_{z}^{2} J_{z}+\lambda_{x}^{2} J_{x}\right) \\
I_{Z Z}=\lambda_{x} \lambda_{y} \lambda_{z}\left(\lambda_{x}^{2} J_{x}+\lambda_{y}^{2} J_{y}\right) \\
I_{X Y}=\lambda_{x}^{2} \lambda_{y}^{2} \lambda_{z} I_{x y} \\
I_{X Z}=\lambda_{x}^{2} \lambda_{y} \lambda_{z}^{2} I_{x y} \\
I_{Y Z}=\lambda_{x} \lambda_{y}^{2} \lambda_{z}^{2} I_{x y}
\end{gathered}
$$

where

$$
\begin{aligned}
& J_{x}=\frac{1}{2}\left(I_{z z}+I_{y y}-I_{x x}\right) \\
& J_{y}=\frac{1}{2}\left(I_{z z}+I_{x x}-I_{y y}\right)
\end{aligned}
$$

$$
J_{z}=\frac{1}{2}\left(I_{x x}+I_{y y}-I_{z z}\right)
$$

$I_{X X}, I_{Y Y}$, and $I_{Z Z}$ are the moments of inertia about the $X$ ', Y', and Z'-axis, respectively.

$I_{X Y}, I_{X Z}$, and $I_{Y Z}$ are the products of inertia in OX'Y'Z'.

$I_{x x}, I_{y y}$, and $I_{z z}$ are the moments of inertia about the x', y', and z', respectively.

$I_{x y}, I_{x z}$, and $I_{y z}$ are the products of inertia in ox'y'z'.

- Inertial tensor for scaled dummy can also be calculated in OXYZ using Equation (10):

$$
I_{O X Y Z}=Q^{T} I_{O X^{\prime} Y^{\prime} Z^{\prime}} Q
$$

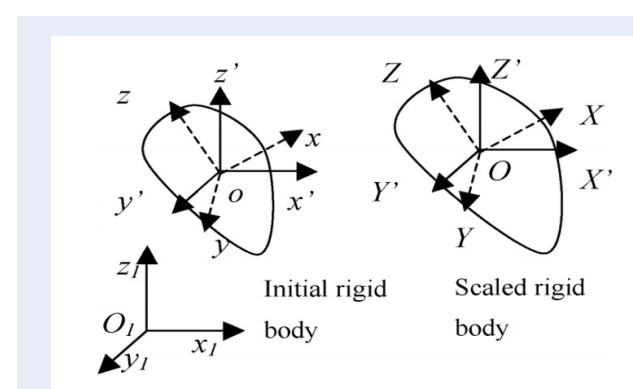

Figure 4: Rigid body in inertial and scaled configurations $^{3}$

\section{Scaling of joint properties}

Every part of dummy model is connected using joints whose stiffness is mainly defined by forcedisplacement and moment-angle curves. Normally, joint characteristics of a human body are directly measured in order to obtain accurate results, but there is no such data available for Vietnamese joint characteristics. As a result, an approximation solution is needed to scale joint properties, and Untaroiu ${ }^{6}$ suggests a formula for this purpose:

$$
M_{\text {scaled }}=\lambda_{x} \lambda_{y} \lambda_{z} M_{H y b r i d}
$$

where $\lambda_{x} \lambda_{y} \lambda_{z}$ are determined from geometric scaling, $M_{\text {scaled }}$ and $M_{\text {Hybrid }}$ are moment and force curve respectively.

Using Equation (11), moment and force curves can be scaled to match Vietnamese dummy's joint properties in a reasonable way. 

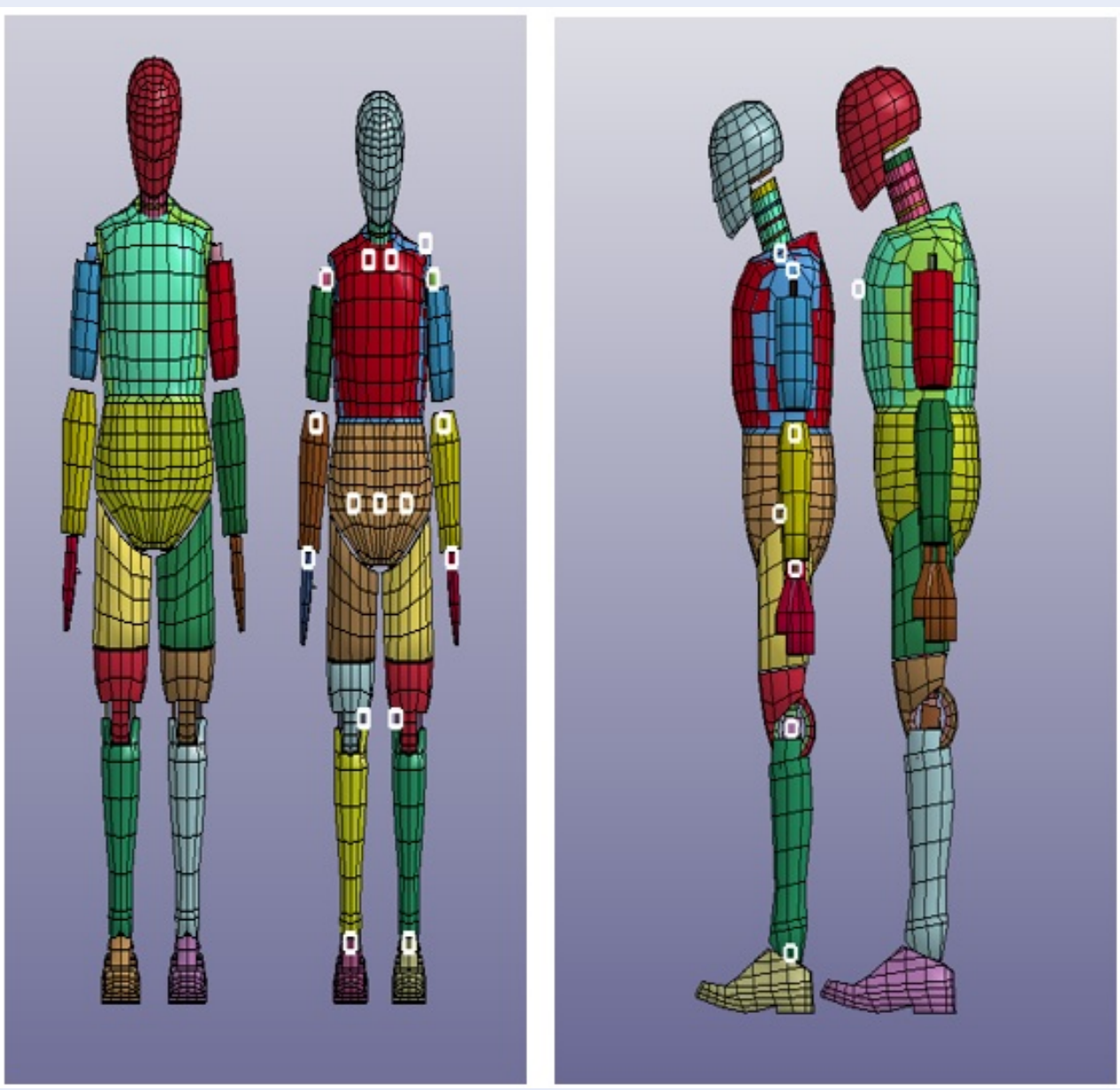

Figure 3: Result of geometric scaling where Hybrid III $50^{\text {th }}$ is the one with red head, and Vietnamese dummy is the other

\section{HEAD INJURY}

Pedestrian head injuries are the main causes of pedestrian fatalities and disabilities in pedestrian to motor vehicle collision ${ }^{7}$. The mechanisms and behaviors of pedestrian head in collision are unpredictable in real cases. In spite of the development of automotive safety industry, the only injury criteria in wide use is the Head Injury Criterion (HIC), which was developed in the $90 \mathrm{~s}$.

\section{Head injury criterion}

The Head Injury Criterion (HIC) was first idealized in 1961 by Gadd in his research. He also developed his criterion - Gadd severity index (GSI). After that, it was truly finalized by Versace (1971), which known as a function of average linear acceleration correlated to the Wayne State University tolerance curve. But it was first only published widely by the US National
Highway Traffic Safety Administration (NHTSA) and is expressed as:

$$
H I C=\max \left[\frac{1}{t_{2}-t_{1}} \int_{t_{1}}^{t_{2}} a(t) d t\right]^{2.5}\left(t_{2}-t_{1}\right)
$$

where $t_{2}$ and $t_{1}$ : two arbitrary times during acceleration pulse. Linear acceleration a is a function of time (seconds), which measured in multiples of gravity acceleration (g's).

The average linear acceleration $\bar{a}$ of $a(t)$ between two phases $t_{2}$ and $t_{1}$ can be expressed as:

$$
\bar{a}=\frac{1}{t_{2}-t_{1}} \int_{t_{1}}^{t_{2}} a(t) d t
$$

And the head injury criterion (HIC) can be calculated as:

$$
\begin{aligned}
H I C & =\max \left(t_{1} \text { or } t_{2}\right) \\
& \times\left\{\left(t_{2}-t_{1}\right)\left[\frac{1}{t_{2}-t_{1}} \int_{t_{1}}^{t_{2}} a(t) d t\right]^{2.5}\right\}
\end{aligned}
$$


where HIC is the maximum value between the impact time $t_{2}$ and $t_{1}$ of the brackets \{\} , while the index 2.5 based on the real case accidents.

Since the HIC index had an important part in automotive safety industry, there are still some limitations on HIC as an injury severity criterion such as:

- Rotating acceleration of head is skipped.

- Only hard contacts are taken into account.

\section{Abbreviated injury scale}

The Abbreviated Injury Scale (AIS) shown in Table 2 points out risk of fatality for a given injury level correlated to the head injury criterion (HIC). There are six injury levels from 1 (minor injuries) to 6 (fatal, nonsurvivable).

\section{RESULT AND DISCUSSION}

When a car hits pedestrian, there are two factors that need to be considered: accelerations and the head injury criterion. According to the limitations of HIC index, only linear acceleration is taken into account. For this research, angular acceleration is not a serious deficiency, since the mechanism of head in the first stage of impact (car hitting to pedestrian) likely moved linearly.

A simulation with the original Hybrid III $50^{\text {th }}$ Percentile was conducted to compare the result with IAdummy - the FE modeled dummy based on a dummy built by Elmasoudi ${ }^{8}$. The IA-dummy is a $50^{\text {th }}$ percentile male dummy so we can correlate the result from our simulation to their experiment data to validate the right methods of our simulation setup. Simulation results are presented in Figure 5 and Figure 6. According to the simulation comparing to experiment results from Figure 6, the acceleration trends in $\mathrm{x}$-direction of simulation likely to exact from experiment data. The peak data of both acceleration results are around $70-90$ g's.

Moreover, resultant acceleration following time is plotted in Figure 7. HIC calculated by using Equation (13) and obtained by LS-DYNA has similar value of 427 , which is closely matched to result in research of Elmasoudi on the pedestrian impact dummy ${ }^{8}$. According to Table 2, the HIC $=427$ could correlate to AIS $=1$, which means there's no any severely injured to pedestrian.

\section{CONCLUSION}

A dummy with Vietnamese biomechanical characteristics named V-Dummy is created by applying geometry, inertial properties and joint properties scaling algorithm on Hybrid III 50th dummy. Numerical simulation approach is also validated. HIC in case of sedan- Hybrid III $50^{\text {th }}$ dummy crash at $40 \mathrm{~km} / \mathrm{h}$ is comparable with other experimental and numerical simulation results which are published. However, if Hybrid III $50^{\text {th }}$ dummy is represented for Vietnamese, the result is underestimated the risk of head fatalities. Therefore, V-Dummy will be applied for further study.

\section{ACKNOWLEDGEMENT}

This research is funded by Vietnam National University Ho Chi Minh City (VNU-HCM) under grant number C2019-20-04.

Numerical simulation in this paper is conducted in High Performance Computing Laboratory (HPC Lab), Faculty of Computer Science \& Engineering, Ho Chi Minh City University of Technology - HCMUT, Vietnam National University - VNU.

\section{LIST OF ABBREVIATIONS}

FEM: Finite Element Method.

HIC: Head Injury Criterion.

AIS: Abbreviated Injury Scale

\section{COMPETING INTERESTS}

The authors pledge that there are no conflicts of interest in the publication of the paper.

\section{AUTHOR CONTRIBUTION}

Hung Anh Ly takes responsibility as principal investigator, brainstorming ideas for writing articles and reviewing articles; Orientation, evaluation and interpretation of simulation results.

Huy Anh Nguyen has participated in creating new dummy, supporting writing articles.

Dinh Bao Nguyen has participated in running simulations, analyzing results and verifying results, supporting writing articles.

\section{REFERENCES}

1. World Health Organization: Violence and Injury Prevention [Online] [Accessed 2511 2018];Available from: https://www.who.int/violence_injury_prevention/road_traffic/ countrywork/vnm/en/.

2. Quốc gia nào có tỉ lệ tai nạn giao thông cao nhất thế giới [Online] [Accessed 2511 2018];Available from: https://baomoi.com/quoc-gia-nao-co-ty-le-tai-nan-giaothong-cao-nhat-the-gioi/c/22591282.epi.

3. Hybrid III [Online] [Accessed 2512 2018];Available from: https: //en.wikipedia.org/wiki/Hybrid_III.

4. Quyên $\mathrm{H}$. Sau 25 năm người Việt chỉ cao tăng $3 \mathrm{~cm}$ chiêuu cao [Online] [Accessed 2511 2018];Available from: https://news.zing.vn/sau-25-nam-nguoi-viet-chi-tang-3-cmchieu-cao-post816342.html.

5. Hyncik L. On scaling of human body models. University of West Bohemia. 2007; 


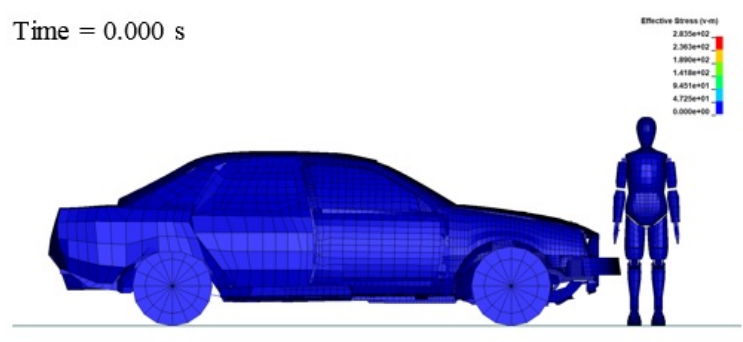
sseosmenes


Time $=0.070 \mathrm{~s}$
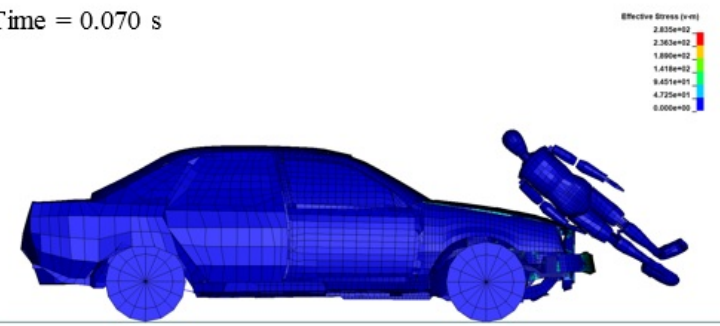

nun

Time $=0.125 \mathrm{~s}$

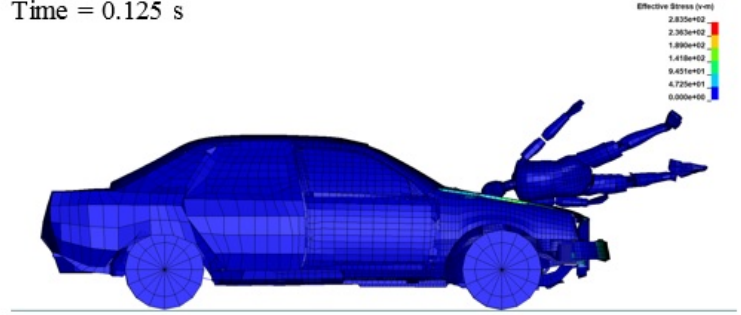

Time $=0.150 \mathrm{~s}$

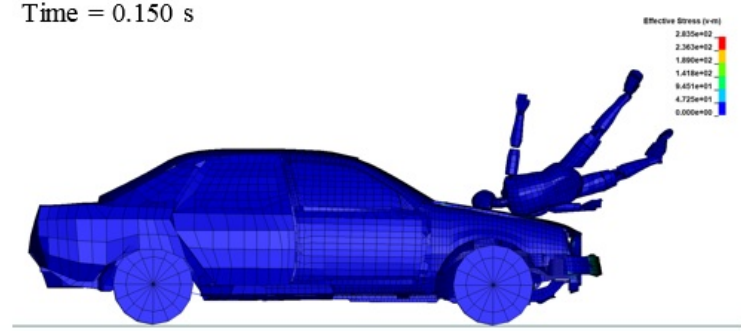

Figure 5: Key frames from simulation 


\begin{tabular}{|c|c|c|}
\hline HIC & AIS & Level of head injury - brain concussion \\
\hline $135-519$ & 1 & Headache or dizziness; light brain or cervical injuries \\
\hline $520-899$ & 2 & $\begin{array}{l}\text { Concussion with or without skull fracture; less than } 15 \text { mins unconsciousness; } \\
\text { face/nose fracture }\end{array}$ \\
\hline $900-1254$ & 3 & $\begin{array}{l}\text { Concussion with or without skull fracture; more than } 15 \text { mins unconsciousness, } \\
\text { but without severe neurological damages; no damages of spiral cord }\end{array}$ \\
\hline $1255-1574$ & 4 & Skull fracture with severe damage injuries \\
\hline $1575-1859$ & 5 & $\begin{array}{l}\text { Concussion with or without skull fracture with hemorrhage and/or critical neu- } \\
\text { rological damages; unconsciousness greater than } 12 \text { hours }\end{array}$ \\
\hline$>1860$ & 6 & Non-survivable \\
\hline
\end{tabular}

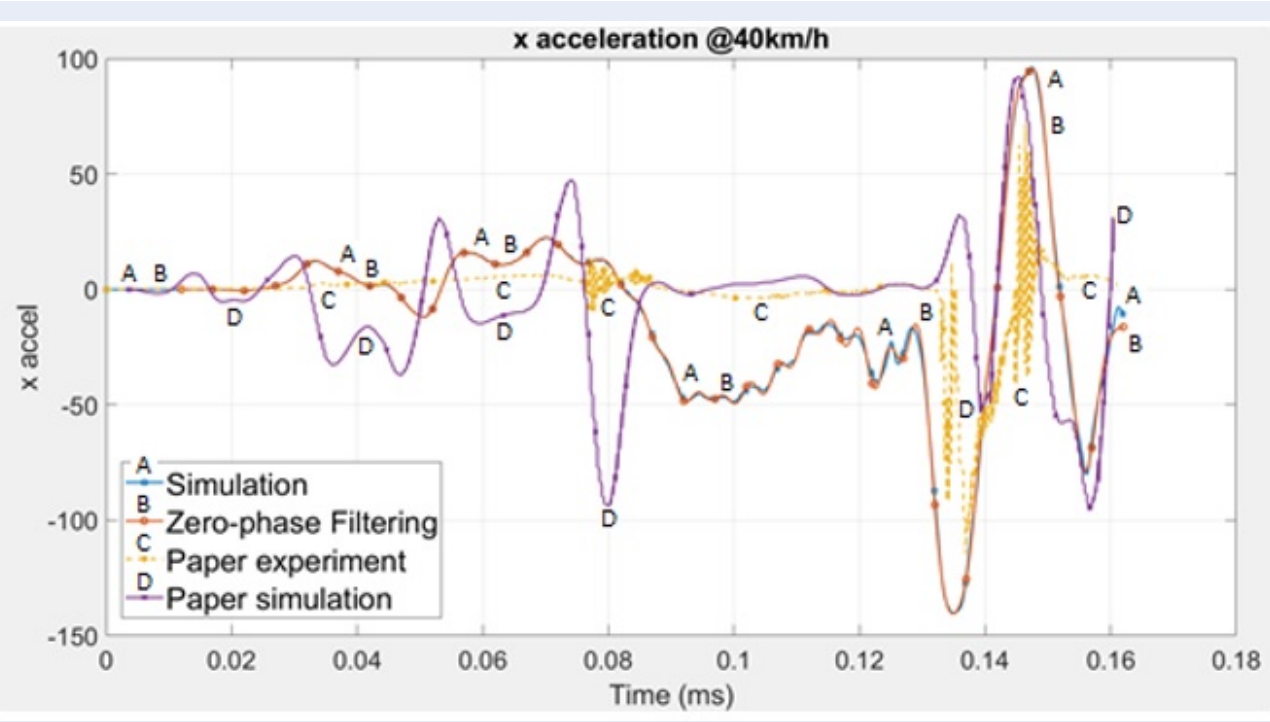

Figure 6: Simulation - Experiment validating results

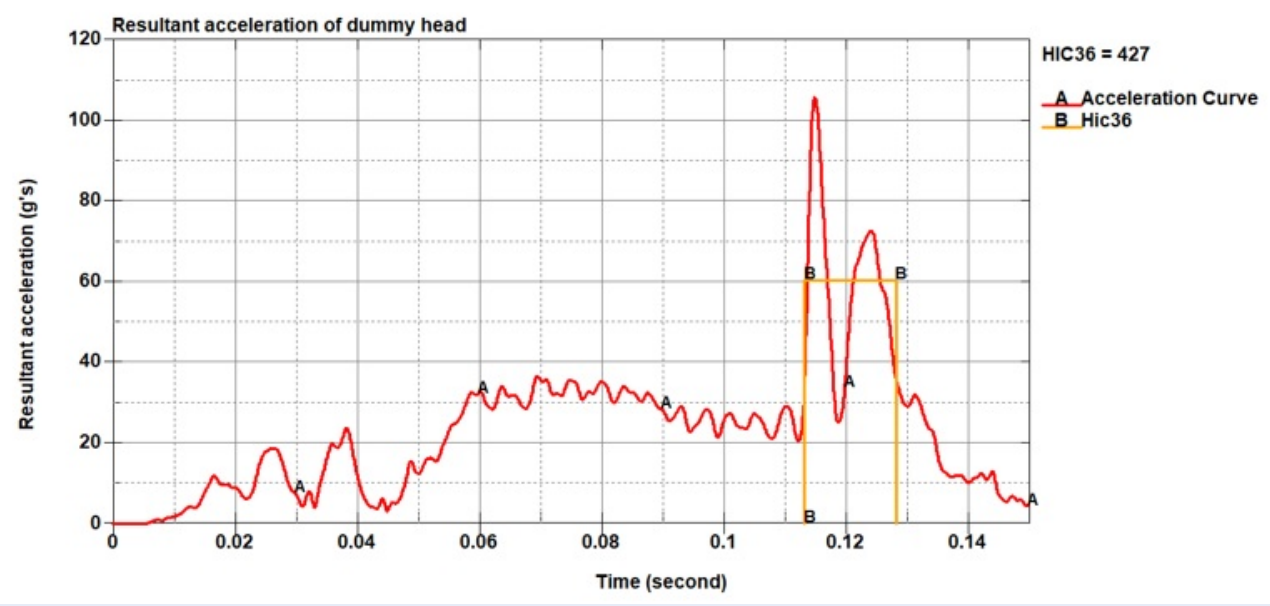

Figure 7: Head Injury Criterion (HIC) results 
6. Untaroiu CD. A study of the pedestrian impact kinematics using finite element dummy: the corridors and dimensional analysis scaling of upper-body trajectories. International Journal of Crashworthiness. 2008;13:468-478.

7. Fredriksson R, Håland Y, Yang J. Evaluation of a New Pedestrian Head Injury Protection System with a Sensor in the Bumper and
Lifting of the Bonnet's Rear Edge. Proceedings of the 17th International Technical Conference on the Enhanced Safety of Vehicles. 2001;:

8. Elmasoudi $\mathrm{S}$. Finite element modelling of a pedestrian impact dummy. KTH Royal Institude of Technology, Sweden. 2015;. 


\title{
Phương pháp thay đổi kích thước và kiểm chứng mô hình phần tử hữu hạn của hình nhân học trong mô phỏng an toàn va chạm xe ô tô.
}

\author{
Lý Hùng Anh ${ }^{1,2}{ }^{*}$, Nguyễn Đình Bảo ${ }^{1,2}$, Nguyễn Anh Huy ${ }^{1,2}$
}

${ }^{1}$ Khoa Kỹ thuât Giao thông, Trường Đai học Bách khoa

${ }^{2}$ Đại học Quốc gia Thành phố Hồ Chí Minh

Liên hệ

Lý Hùng Anh, Khoa Kỹ thuật Giao thông, Trường Đại học Bách khoa

Đại học Quốc gia Thành phố Hồ Chí Minh

Email: lyhunganh@hcmut.edu.vn

Lịch sử

- Ngày nhận: 06-3-2019

- Ngày chấp nhận: 17-6-2019

- Ngày đăng: 31-12-2019

DOI : 10.32508/stdjet.v2iS12.468

\section{Check for updates}

\section{Bản quyền}

๑) ĐHQG Tp.HCM. Đây là bài báo công bố mở được phát hành theo các điều khoản của the Creative Commons Attribution 4.0

International license.

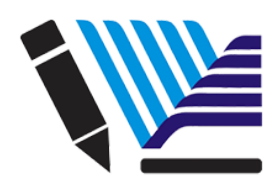

VNU-HCM Press

\section{TÓM TẮT}

Đối với nghiên cứu các vụ tai nạn xe ô tô - người đi bộ, có hai phương pháp phổ biến có thể được sử dụng: tiến hành các thử nghiệm va chạm với hình nhân thật và mô phỏng các vụ tai nạn xe hợi trên máy tính. Cách đầu tiên vẫn thường được tiến hành và cho kết quả tốt so với tác động thực tế của xe; tuy nhiên, nhược điểm của nó là thiết bị thử nghiệm rất đắt tiền và thường tốn nhiểu thời gian hơn cách sau vì sau mỗi lần thử nghiệm, các thiết bị thử nghiệm cũng như hình nhân cần được sửa chữa và hiệu chỉnh để sẵn sàng cho lần thử nghiệm tiếp theo. Do đó, mô phỏng thử nghiệm va chạm bằng phương pháp phân tử hữu hạn ngày càng phổ biến trong ngành công nghiệp ô tô vì tính khả thi và tiết kiệm chi phí. Phần lớn các mô hình hình nhân phần tử hữu hạn được sử dụng trong mô phỏng va chạm. Đặc biệt, hình nhân Hybrid III $50^{\text {th }}$ thường được sử dụng, mô hình này được xây dựng dựa trên chiêu cao và cân nặng trung bình của nam giới Bắc Mỹ. Vi vậy, cần phải phát triển một thuật toán tỷ lệ để chia tỷ lệ kích thước tham chiếu thành kích thước mong muốn mà không cần xây dựng lại toàn bộ mô hình. Trong bài báo này, hình nhân Hybrid III được cung cấp bởi LS-DYNA được thu nhỏ cho phù hợp với đặc điểm nhân chủng học của người Việt Nam. Thuật toán lấy tỷ lệ được thực hiện bao gôm hình học, tính chất quán tính và tính chất của khớp. Để ước tính mức độ chấn thương đâuu - chấn động não bằng cách sử dụng mô phỏng số, mối tương quan giữa Chỉ số chấn thương đầu $(\mathrm{HIC})$ và Thang đo chấn thương (AIS) được giới thiệu. Ngoài ra, ứng xử hình nhân Hybrid III trong mô phỏng va chạm được trình bày qua các hình ảnh theo thời gian. Phương pháp mô phỏng số được kiểm chứng bằng cách so sánh kết quả gia tốc đầu và HIC thu được từ nghiên cứu này với dữ liệu thực nghiệm và kết quả mô phỏng số trong các bài báo khác.

Từ khoá: An toàn trong va chạm, tai nạn của người đi bộ, hình nhân học, HIC, gia tốc
Trích dẫn bài báo này: Anh $L H$, Bảo N D, Huy N A. Phương pháp thay đổi kích thước và kiểm chứng mô hình phần tử hữu hạn của hình nhân học trong mô phỏng an toàn va chạm xe ô tô.. Sci. Tech. Dev. J. - Eng. Tech.; 2(SI2):Si105-SI113. 